\title{
Military Cooperation between Russia and Belarus: Theoretical and Practical Perspectives
}

\begin{abstract}
The article analyses the dynamics of military cooperation between Russia and Belarus at the time when Russia's aggression against Ukraine revealed president Vladimir Putin's objective to consolidate control over his interest zone in the nearest post-soviet area at all hazards. This could be called the time-period during which endurance of military cooperation is increased and during which Russia demonstrates its principle ambition to expand the use of military capabilities while leaning on Belorussian military capabilities, military infrastructure and territory as a bridgehead for potential military actions. For this reason, the aim of the paper is to outline the key factors which determine military integration of the both countries, or, more specifically, to discuss orientations and objectives set forth for building military cooperation as laid down in the documents regulating military policy, to discuss and assess practical cases of strengthening of interaction between military capabilities (strategic military exercises), to reveal the accomplishments of military and technical cooperation, problems it might pose and potential prospects of its development.
\end{abstract}

\section{Introduction}

In the relationship between Belarus and Russia, the field of military cooperation could be highlighted as the most stable over the past three decades, though the relationship of the both countries is accompanied by alleged, staged and still emerging disagreements or flashes of short-term tension which notably remind of movement of meteors, which illuminate the sky, towards the sinful planet of Earth. Almost a decade ago, political scientist Gražvydas Jasutis called the military cooperation between Russian and Belarus in his indepth study as a military alliance since long-term bilateral relationship in the military area had gone through four stages of complex military integration from the start of activity coordination as follows: legal-contractual, institutio-

\footnotetext{
* Dr Virgilijus Pugačiauskas is a Professor of the Department of Political Science of the General Jonas Žemaitis Military Academy of Lithuania. Address for correspondence: Šilo 5A, LT- 10322 Vilnius, Lithuania, tel. +370 5 2103582, e-mail: virgilijus.pugaciauskas@lka.lt
}

DOI: 10.2478/lasr-2019-0010

(C) Virgilijus Pugačiauskas, 2019

(C) Military Academy of Lithuania, 2019 
nal, instrumental and functional dependence, i.e. reached the highest stage of military integration.

In his view, "disintegration of this alliance is highly unlikely since military capabilities of the countries have achieved a high level of interoperability and the created structures partly contribute to the strengthening of integration. Economic and political controversies between Russia and Belarus have no critical impact on the evolution of the military alliance. Taking internal and external factors into consideration, it is likely that the military Russian-Belorussian alliance will not only dominate in the post-soviet space but will rather get stronger in the mid-term perspective." This assessment has to do with the period of positive relationship between Russia and the Western world; therefore, it would be reasonable to elaborate on whether one could record new changes and possibly new prospects in the context of Russia's confrontation with the West.

This article has the aim to analyse the dynamics of military cooperation between Russia and Belarus at the time when Russia’s aggression in Ukraine revealed president Vladimir Putin's objective to entrench control over his interest zone in the nearest post-soviet area at all hazards. The Russian strategy of enhancement of military power and building of relationship with the West on the basis of the strategy has naturally increased geopolitical significance and military strategic importance of Belarus. Its geostrategic location (land border of almost 1,000 kilometres and 200 kilometres to the military fore-post in the Kaliningrad Oblast) makes Belarus important as the so-called "buffer zone"2 which isolates Russia from the West and protects the territory of the latter. According to the president of Belarus Alexander Lukashenko, "Belarus is the main fore-post in the direction of the West, including the direction of Russia"3. Should Russia start a war against the West, Belarus would also be an important territory for pooling military capabilities and an area of departure for moving towards the West as regards an attack operation. Due to its proximity to the Kaliningrad Oblast, Belarus is considered a territory of critical importance

\footnotetext{
${ }^{1}$ Jasutis G., Karinio aljanso patvarumo tyrimas: Rusijos ir Baltarusijos atvejis. Daktaro disertacija. Vilnius: Vilniaus universitetas, 2011, p. 33-48, 137. [Study on Endurance of Military Alliance: Case of Russia and Belarus. Doctoral Thesis. Vilnius: Vilnius University. 2011. p. 33-48, 137] - in Lithuanian.

${ }^{2}$ Colibasanu A., Russia, Belarus and a Catch-22, https://geopoliticalfutures.com/russia-belarus-catch-22/; Fedirka A., Belarus: Between a Rock and a Hard Place, Geopolitical futures, https://geopoliticalfutures. com/belarus-between-a-rock-and-a-hard-place [accessed on 03/02/2018]; Kłysiński K., Żochowski P., The End Of The Myth of a brot herly Belarus? Russian soft power in Belarus after 2014: the background and its manifestations, OSW Studies, 2016, s. 47-49 arba https://www.osw.waw.pl/en/publikacje/osw-studies/2016-11-07/end-myth-a-brot-herly-belarus-russian-soft-power-belarus-after [accessed on 05/02/2018]. ${ }^{3}$ Президент раскритиковал нежелание России укреплять армию Беларуси и других членов ОДКБ, https://news.tut.by/economics/580911.html [accessed on 05/02/2018].
} 
for Russia, should the latter decide to unblock this enclave surrounded by the West and to guarantee communication with it by land. For the aforementioned reasons, Russia is extremely interested in strengthening its impact on Belarus; whereas the latter uses every possible occasion to demonstrate that it has the right to an opinion different from the policy implemented by its main ally. In the past few years, in particular, Russia's efforts to deepen the integration process based on the existence of the Russian-Belarussian alliance and build endurance as well as to strengthen military cooperation have become especially pronounced.

Consequently, the article will search for the answers to the following questions: what the new military cooperation plans of the countries are, whether military integration undergoes dramatic changes, what the prospects of such integration in the short-term period are. The focus will be put on two essential complex components of military integration, namely, on joint military exercises and on military and technical cooperation.

\section{Strategy, Tactics and Practice of Interoperability between Military Capabilities}

Close cooperation between Russia and Belarus in the post-soviet period has been accompanied by the strategic concept to put into action the idea of creation of an allied country since the early 1992; however, the process has been lengthy and slow. Recently, Russia has initiated practical implementation of the agreement on a unified state signed back in 1999 with the aim to guarantee an increasingly bigger control over the domestic and foreign policy of Belarus. Competence of this supranational formation also encompasses the allocated joint military functions which include the creation of united regional military capabilities, the development of a joint defence policy and military and technical cooperation.

Military cooperation between Russia and Belarus can be traced in the main documents of military policy, namely, doctrines, of the both countries. For instance, the 2014 Russian military doctrine stipulates that in case of an attack against the allied state ${ }^{4}$, Russia will consider this as aggression and will take counter-measures. Besides, the priority of military cooperation with Belarus is entrenched and includes coordination of development of national capa-

\footnotetext{
$4^{* *}$ Договор о создании Союзного государства, http://www.soyuz.by/about/docs/dogovor5/ [accessed on $04 / 02 / 2018$ ]
} 
bilities and the use of military infrastructure as well as the formation of joint national defence based on the military doctrine of a joint state ${ }^{5}$. Thus, the focus is exclusively put on anchoring the conditions for the use of the Russian military forces in the neighbouring country.

Belarus, in its turn, devotes much more attention to the relationship with Russia in the military field in its new doctrine. The focus is mostly put on the role of united regional armed forces in the common security dimension, for instance, united actions with Russia in order to ensure security of a unified state in case of military aggression is envisaged as well as the provision of conditions for the country to operate; use of military power for the defence of a unified state is regulated by contracts with Russia; to manage and control united regional armed forces "in the face of growing threat", a collegial military institution is formed and development of cooperative relations in the sector of defence is discussed ${ }^{6}$. It can be seen that the Belorussian doctrine defines the joint operation of armed forces in a more accurate manner with the cases and procedures for the use of common regional armed forces set forth, whereas Russia in case of an attack would use military force at its own discretion. Hence different attitudes towards joint defence of the countries are more than evident.

Military cooperation procedures are provided for in the 2001 Military Doctrine of the Unified State and its latest version should come into force in 2019 but its content is not disclosed. The first document lays down broad scale plans and the following key operational directions: unification of command and control systems of Russian and Belorussian armies, technical modernisation of national armed forces based on joint programmes, also joint exercises, and development of military infrastructure necessary for joint use. Logical continuation of implementation of the doctrinal provisions is the composition of two military structures - unified regional air defence system and regional land military group. They both must ensure interoperability of defence forces of the both countries in case of a conflict with the West. To make sure that these structures will function, specific actions intended for strengthening of integration have been provided for, namely, improvement of common control systems, preparation of mobilisation resources, development of unified system

\footnotetext{
${ }^{5}$ Военная доктрина Российской Федерации, https://rg.ru/2014/12/30/doktrina-dok.html [accessed on 06/02/2018].

${ }^{6}$ Военная доктрина Республики Беларусь, http://www.pravo.by/document/?guid=12551\&p0=H1160041 $2 \& p 1=1$ [accessed on 06/02/2018].
} 
of technical maintenance and logistic bases ${ }^{7}$. The new doctrine should envisage a new integration stage leading to a deeper build-up of armed forces of the both countries. In fact, signing procedures of the latter document are delayed by Belarus: the document had to be approved at the end of 2018 and Russia put into effect all the required procedures ${ }^{8}$.

As regards the formation of united regional armed forces, as a priority cooperation task should be finding out what military forces of the allies are attributed to this group. Supposedly, this military compound includes all Belorussian armed forces operating in its western part and other Russian military units according to the plan. Capabilities of the countries in peace time are subordinate to their military commands. Meanwhile, in wartime a joint top level command should be composed to take command over the joint forces of both countries. The assumption about formation of joint forces and their composition is also confirmed by a Belorussian expert Nikita Dunec ${ }^{9}$, who is of the view that the Russian and Belorussian group includes all Belorussian military forces and the $20^{\text {th }}$ army of the Russian Western military district with all attributed units of central and regional level control, whereas the optimum combat composition is established during joint exercises. In this case, Mr Dunec' assessment regarding the Russian group may not be quite accurate since after the year 2014 the said $20^{\text {th }}$ army was meant to implement Russia's interests in terms of Ukraine. It is more likely that in case of a war, the $1^{\text {st }}$ tank army which was restored in 2017 and units of which are deployed near the Belorussian border could be used for operations and actions.

Military cooperation between Russia and Belarus is mostly put into effect in joint military strategic exercises; for this reason, it is reasonable to identify quantitative parameters of such trainings and possible potential qualitative shifts. From 2005, exercises take place every two years in the territories of the two countries alternately. These are known as Schyt Sojuza and Zapad to the general public. After the annexation of Crimea in 2015, the scheduled exercise Schyt Sojuza 2015 took place in the western part of Russia. Joint for-

\footnotetext{
${ }^{7}$ Военная доктрина Союзного государства, https://www.postkomsg.com/documentation/document/472/ [accessed on 06/02/2018].

${ }^{8}$ Путин одобрил проект военной доктрины Союзного государства, https://rg.ru/2018/12/19/putinodobril-proekt-voennoj-doktriny-soiuznogo-gosudarstva.html [accessed on 07/02/2018].

9 Дунец Н. А., Военно-политические аспекты функционирования региональной группировки войск Беларуси и России, http://elib.bsu.by/bitstream/123456789/184865/1/Дунец_Истор_Ч.1-067-077.pdf. [accessed on 09/02/2018]; Соглашение между Российской Федерацией и Республикой Беларусь о совместном обеспечении региональной безопасности в военной сфере, http://www.mid.ru/foreign_policy/international_contracts/2_contract/-/storage-viewer/bilateral/page-264/47455 [accessed on $10 / 02 / 2018]$.
} 
ces of the Western military district $-8,000$ of military staff (including 1,300 Byelorussians) and around 400 units of military equipment, including aviation and vessels, participated in the surroundings of St. Petersburg and Pskov. The focus of the exercise was a defensive battle with a transition to an attack for coordination of movements and actions, for improvement of skills while taking command over the joint headquarters; in addition, attention was given to the compatibility of modern communications ${ }^{10}$.

To analyse military integration and interoperability of the two countries, the best and the latest object of research could be the strategic Russian and Belorussian training Zapad 2017. According to official sources, the purpose of the exercise was improvement of compatibility between different level headquarters, binding of new prospective military and armament control systems, approval of new statutory documents, practice of all level of military officers while planning military exercises of similar type. It should be noted that manoeuvres in Belarus were merely a constituent part of huge third stage strategic exercise covering the entire European part of Russia. Interoperability is conveyed through joint and coordinated actions of the both countries. As for Belarus, about 12,700 members of military staff participated in the manoeuvres in the Belorussian territory, among them 5,500 Russian paratroopers, tankers, pilots, signallers and infantrymen, 70 airplanes and helicopters, up to 680 pieces of military equipment, including about 250 tanks and up to 200 artillery guns, rocket systems and mine throwers ${ }^{11}$. Interestingly, the provided statistical data differs remarkably. For example, based on the press release by the chief of the International Military Cooperation Department of the Defence Ministry of Belarus General Oleg Vojnov, the manoeuvres were attended by 10,175 Belorussian and 3,100 Russian servicemen (those who participated in the territory of Belarus), 138 tanks, of them: 98 Russian military vehicles, 231 (104) of artillery and rocket systems, accordingly, 49 airplanes and 27 helicop-

\footnotetext{
${ }^{10}$ Белялова Н., Российско-белорусские учения „Щит Союза“. Досье, https://tass.ru/info/2248332 [accessed on 11/02/ 2018]; Российско-белорусские учения „Щит Союза-2015“ стартуют на западе РФ, https://ria.ru/20150910/1240961439.html [accessed on 11/02/2018]; Газета Министерства обороны Республики Беларусь „Белорусская военная газета. Во славу Родины“, https://vsr.mil.by/2015/09/24/poglavnoj-magistrali\%e2\%80\%a6-svyaznoj [accessed on 11/02/ 2018]; Шойгу: подготовка к белорусскороссийскому учению „Щит Союза - 2019“ перешла в активную фазу, http://www.soyuz.by/news/ security/43547.html [accessed on 12/02/2018].

${ }^{11}$ Учения „Запад-2017“: проверка „нервной системы“ российской армии, https://tass.ru/armiyai-opk/4573331 [accessed on 11/02/2018]; Легенды „Запада“. Что показали российско-белорусские стратегические учения 2017 года, https://rg.ru/2017/09/20/chto-pokazali-rossijsko-belorusskie-ucheniia-zapad-2017.html [accessed on 11/02/2018].
} 
ters $^{12}$. The exercise served as a perfect tool for testing the abilities and capacity of the armed capabilities of both countries attributed to the unified regional armed forces of Russia and Belarus and the united regional system of air defence meant to operate jointly. Although the main actions of the exercise took place in Belarus, the exercise located in Russia could possibly have direct links to the activities conducted in Belarus. Therefore, it should be emphasised, that the official statistical data is not reliable, especially, when talking about the exercise in the territory of Russia - in fact, the true number of servicemen and military equipment exceeded the officially declared one several times ${ }^{13}$. There is one more important aspect in relation to the exercise which should be highlighted: the permanent presence of the Russian military units in the territory of Belarus is considerably more numerous than of the Belorussian militaries in Russia.

In the territory of Belarus, exercises were organised in eight firing grounds throughout the entire territory proportionally, stretching from Vitebsk to Brest. As per official statement, during the exercises, units of both countries practiced defensive and offensive operations related to the defence of the national border and military objects, destruction of enemy diversions and intelligence groups, terrorist groups and exercises of a battle of defensive character. It is important to emphasize again that an evident disproportion between the declared objectives and the measures used for their implementation can be clearly seen, i.e. during the exercise, the army or its special operation forces destroy(s) terrorists. Lightly-armed and scarce "terrorist" groups are fought against by the armed units of the both countries which use heavy weaponry tanks, aircraft and artillery. It should be noted that small terrorist groups often operate in the territory of Poland or Lithuania or force their way from these countries to Belarus ${ }^{14}$. The assumption could be made that the exercise and the training is designed not quite for the combat against terrorist or illegal armed compounds.

It is difficult to objectively understand who of the said terrorist or illegal armed groups named as opponents in the exercise could have the forces

\footnotetext{
12,Запад-2017“ Дневник белорусско-российских военных учений, https://naviny.by/ article/20170920/1505918347-zapad-2017-dnevnik-belorussko-rossiyskih-voennyh-ucheniy [accessed on 13/12/2018].

${ }^{13}$ Petraitis D., "The Anatomy of Zapad-2017: Certain Features of Russian Military Planning", Lithuanian Annual Strategic Review, 2017-1018, vol. 16, p. 229-268; State Security Department of Lithuania, National Security Threat Assessment 2018, https://www.vsd.lt/wp-content/uploads/2019/02/2019-Gresmes-internetui-EN.pdf [accessed on 14/02/2018].

${ }^{14}$ Условным противником на учениях «Запад-2017» будет белорусский регион, https://www.svoboda. org/a/28704972.html [accessed on 15/02/2018].
} 
capable of conducting offensive actions in the territory from St. Petersburg in Russia to Brest in Belarus. It seems that the joint military mechanism of Russia and Belarus operating in the theatre of war of this strategic extent is actually targeted not at the terrorists or illegal armed groups at all. Weapons used by the joint forces and the size of forces give the idea that the implied (hypothetical) opponent of the Russians and Belarusians is numerous regular forces equipped with technically advanced armament. Another assumption which might be supported by the instances of Georgia and Ukraine is that concentration of offensive armament and actions intended for its use are exercised not for defence but for implementation of a rapid and short-term military objective of offensive nature.

Changes in the Russian and Belorussian exercises show up after comparison of statistical data with the previous exercises Zapad 2013. The number of participating servicemen increases on both sides of the partners, however, on the Russian side more. The number of military equipment, given possible non-objective details, was more or less similar, except for the heavy armament, e.g., tanks, the number of which doubled - from 78 to 138 . Another distinct difference is the space of the exercise: from two firing grounds at the borders of Lithuania and Poland (of Brest and Gozha in the district of Grodno) covered the entire territory of Belarus. Thus the scope and the territory of the scheduled military exercises gradually expand ${ }^{15}$.

It should be stressed that changes in the interoperability are also demonstrated by other bilateral exercises which are of no less importance but have been less covered by press. In 2017, from May to September a number of joint exercises of different nature and extent took place: from 19 to 25 May, the territory of Belarus hosted radio electronic combat (REC) exercise with 1,500 servicemen participating; in August, logistical exercises were conducted in two stages: 2,500 of Belorussian and 3,000 of Russian servicemen took part in intensive exercises in the territory of Belarus focusing on the actions by engineering, communication, tanks, chemical weapon and air space defence units. During the latter summer exercises, the Russian aircraft landed in the Belorussian airfields ${ }^{16}$. Compared to the previous joint exercises carried out before 2014, a significant increase in the extent of training can be seen. Hence

\footnotetext{
${ }^{15}$ Russia suggests looking for information on Zapad 2013 on the website of the Ministry, http://www.diena. lt/naujienos/lietuva/politika/rusija-informacijos-apie-zapad-2013-siulo-ieskoti-ministerijos tinklalapyje-414901 [accessed on 20/02/2018].

${ }^{16}$ Wilk A., The Zapad-2017 exercises: the information war (for now), Centre for Eastern studies, https:// www.osw.waw.pl/en/publikacje/osw-commentary/2017-09-04/zapad-2017-exercises-information-warnow], [accessed on 22/02/2018].
} 
the course of the exercise is typically intensive - apart from the usual intermediate and preparatory phase as in the case with Schyt Sojuza-2019, as of 2015, both countries organise exercises of their special operation forces, also national and bilateral preparatory exercises.

The political and military authorities of Belarus always emphasise that they develop defence capabilities alone and that their armed forces train for the defence of Belarus and its ally Russia ${ }^{17}$. In this case, the focus should be put on finding out what alleged defence the Belorussian armed forces are getting ready for and how their interoperability with the ally would function. The military leadership of the country give the priority to the formation of special operations forces (SOF) and specialised units, such as electronic warfare (EW), signal intelligence and units of new generation communication systems. These are allocated greater funds and are given priority as regards the supply of the necessary equipment, armament and technology. The Belorussian SOF and specialised units must meet such requirements as mobility and rapid actions, ability to conduct actions in the territory controlled by the enemy. The combat readiness of the Belorussian armed forces shows that the armed forces are trained for warfare under severe and complicated conditions, for new type of warfare in which the importance of special operations forces increases significantly. As a support component to the special operations forces, other capabilities which could support the SOF in combat field are developed in parallel, for instance, aviation and artillery: in 2017-2018, the Byelorussians procured some new helicopters Mi-8MTV-5, aircraft Jak-130, developed and accepted multiple rocket launch system Polonez which is capable of destroying targets at a distance of $300 \mathrm{~km} .{ }^{18}$

The deployment of the Belorussian forces and firing grounds also signals a hypothetical enemy. Military units are deployed and arranged as follows: three of land force brigades and two of three SOF brigades are deployed in Grodno, Slonim, Brest, Marina Gorka and Minsk localities. These localities are found in the western and central part of Belarus not far from the border with Poland and Lithuania. The main military firing grounds used during exercises by the Belorussian armed forces (in Barysaw, Obuz-Lesnovsk, Gozha) are

\footnotetext{
${ }^{17}$ Гучек М., Лукашенко обещает России поддержку армии на западном направлении, https://ria.ru/ world/20161007/1478723524.html [accessed on 30/02/2018].

${ }^{18}$ The National Security Threat Assessment 2018, https://www.vsd.lt/wp-content/uploads/2018/03/LTU. pdf; [accessed on 14/02/2018].
} 
also in the western and central part of the country ${ }^{19}$. Evidently, areas of their actions help ensure the protection of the Russian forces and their preparation for actions aimed against the West, which fully corresponds to the agreements between Russia and Belarus on joint actions in the field of defence ${ }^{20}$.

Having conducted an analysis of deployment, structure and development trends of the Belorussian forces, a statement can be made that in case of a hypothetical war between Russia and NATO, the Belorussian army would possibly carry out the functions of the Russian forward forces (advanced guard), intelligence and protection component. Their possible tasks would be protecting, supplying/equipping and ensuring re-deployment of the Russian forces and their preparation for combat actions. To this end, the concept of the joint Russian and Belorussian logistical bases is in force and is further developed; in other words, the concept of dual basing and host country. For this purpose, infrastructure of the host party is adapted and modernised. Training sessions of interoperability between military and civil institution, rear support services and logistical structures are held ${ }^{21}$. The common logistical concept provides for favourable conditions for the Russian armed forces to prepare for combat actions against NATO expediently.

Awareness-raising of the establishment of a military airbase in the airfield of Babruysk in Belarus is an obvious example of Russia's strategic actions. From 2013, the top political leadership of Russia was putting pressure on the president of Belarus to put into action this project. As the last alternative (the first version spoke of Lida which is $35 \mathrm{~km}$ from the border of Lithuania) the airfield of Babruysk was chosen which could host a relatively small capacity in the initial phase - a squadron of fighter aircraft with $14 \mathrm{Su}-27$ aircraft (two of them used for training) and four supplying helicopters. To compare, only eight NATO airplanes are allocated for the control of the Baltic airspace. Such intention of the ally to deploy military forces in Belarus is not acceptable to Alexander Lukashenko, who officially declares the development of armed for-

\footnotetext{
${ }^{19}$ Украинская оценка состояния и перспектив белорусской армии, https://bmpd.livejournal. com/2878328.html, [accessed on 02/03/2018]; Карта расположения частей ВС Белоруссии, https://armijarossii.blogspot.com/2014/03/blog-post_9.html\#!/2014/03/blog-post_9.html [accessed on 02/03/2018]. ${ }^{20}$ Решение Высшего Совета Сообщества Беларуси и России от 02.04.1997 N 5. „Об Общих принципах военного строительства и использования элементов военной инфраструктуры Беларуси и России“, http://lawru.info/dok/1997/04/02/n104196.html [accessed on 02/03/2018]; Решение № 4 Высшего Совета Союза Беларуси и России. О Концепции совместной оборонной политики Беларуси и России, http://www.conventions.ru/view_base.php?id=14630 [accessed on 02/03/2018].

${ }^{21}$ Завершился очередной этап совместных специальных учений материально-технического обеспечения Вооруженных Сил Российской Федерации и Республики Беларусь, https://tvzvezda.ru/ news/forces/content/1774ab57743aaee0f0129f4272f133e79038f0b288f41582e48b2083ba805e3e [accessed on $03 / 03 / 2018]$.
} 
ces exclusively for the purpose of defence of the country. Alternatively, Belarus suggested that the ally supply the Belorussian troops with modern armament. Russia decided not to exacerbate the problem because the establishment of military bases at the time when processes, which speed up the integration of military forces and modernisation of armament and rapid response forces, are taking place is not among the most critical issues; for this reason, the resolution of this problem has been put aside for the better times. The aviation regiment, in its turn, was deployed to the Kaliningrad Oblast ${ }^{22}$.

An example of implementation of bilateral integration could be the creation of unified regional airspace defence system. As of 2016, according to the official officers of the Belorussian and Russian authorities, the system has been operating in full volume and has conducted the following tasks: control of the Belorussian airspace, surveillance of potential targets moving towards Belarus or in its space, transmission of information to combat units, including the control centre of the Russian armed forces in the Moscow Oblast, military air force headquarters in St. Petersburg and the Russian air defence units in the Kaliningrad Oblast ${ }^{23}$. How does this joint system work in practice?

Referring to the agreement between Russia and Belarus regarding joint air space defence, the Belorussian part would, in case of a hypothetical conflict with NATO, most likely have to counter the attack by enemy rockets and aircraft so as to protect the Belorussian territory and objects. At the same time, it would cover the redeployment of the Russian units to Belarus and would protect them from airstrikes. The unified airspace defence system of Russia and Belarus is most probably supported by all aviation bases of the Belorussian military air forces and air defence units which are equipped with air defence systems, such as Tor-M2E and S-300PS procured from Russia on preferential conditions. The Russian segment is composed of the $6^{\text {th }}$ air and air defence army units (headquarters is in St. Petersburg) subordinate to the leadership of Russia's Western military district. The joint compound also includes five aviation, 10 zenit rocket and five radio-technical and radio-electronic military

\footnotetext{
${ }_{22}^{22}$ Авиабаза в Бобруйске станет „аэродромом подскока“ для авиации РФ, https://charter97.org/ru/ news/2014/10/31/123744/ [accessed on 24/03/2018]; Bohdan S., Moscow gives Belarus Arms and Seems to Abandon Airbase Plans, Belarus Digest, https://belarusdigest.com/story/moscow-gives-belarus-armsand-seems-to-abandon-airbase-plans/ [accessed on 28/03/2018]; Augustis R., Rusijos-Baltarusijos karinès integracijos pokyčiai po Krymo aneksijos. Magistro darbas, Vilnius, 2018, p. 57-59; Changes of Russian-Belorussian Military Integration after the Annexation of Crimea. Master Thesis, Vilnius, 2018, p. 57-59; Алесин A., Вопрос российской авиабазы в Беларуси закрыт. Но у Москвы есть другие вопросы, https:// naviny.by/article/20180116/1516081802-vopros-rossiyskoy-aviabazy-v-belarusi-zakryt-no-u-moskvy-estdrugie [accessed on 16/03/2018].

${ }^{23}$ Спаткай Л., Региональная система ПВО Беларуси и России, http://www.bsblog.info/ [accessed on 08/03/2018].
} 
units $^{24}$. Hence, this compound of military forces and capabilities is not a united compound in terms of organisation but is made of two components, i.e. separately operating national forces of the both countries which coordinate their activities individually. "In case of potential threat or in case of a war", as stipulated in the military doctrine of the unified state, these forces become part of the united regional military forces and a common command structure is formed. According to the agreement dated 2009, by mutual agreement between the presidents, a commander should be assigned to lead the forces who, in peacetime, shall coordinate the actions of the air defence systems of Russia and Belarus. In wartime, the Belorussian air defence system would most probably be subordinate to the Russian air and outer space headquarters. Today the established practice is that as of 2013 the commander of the unified air space defence system can be the commander of air force of Belarus. Actually, he can fulfil the functions of a commander only during joint military exercises, for instance, as was the case during the exercise Zapad-201725. Aircraft of the Russian air force is controlled in the Belorussian airspace by the control centre of the country, and information and tasks are received through the same communication and information channels as the Belorussian pilots receive them. Such system is simpler and more effective in terms of time since the duration of command transmission and assignment of tasks become shorter. Whether structural changes are to be put in effect in an expedient manner in case of a war will depend on the level of readiness.

Regardless of the fact that it took two decades to put a simple task into action, the final result might be seen as a sign of enhancement of the military alliance which enables the countries to expand the opportunities for joint actions and to create the mechanism of command. Evidently, the potentials of these armed forces are sufficient to perform not only defensive functions but to also coordinate actions from Kaliningrad and Belarus and destroy targets in Poland, Lithuania and Latvia and thus aggravate the operation of NATO air forces in the Baltics.

\footnotetext{
${ }^{24}$ Соглашение между Российской Федерацией и Республикой Беларусь о совместной охране внешней границы Союзного государства в воздушном пространстве и создании Единой региональной системы противовоздушной обороны Российской Федерации и Республики Беларусь. http://www.conventions.ru/view_base.php?id=1426 [accessed on 09/03/2018]; Зверев Ю., Зачем Беларуси и России единая система ПВО. Мир перемен, http://mirperemen.net/2016/09/ zachem-belarusi-i-rossii-edinaya-sistemapvo/ [accessed on 10/03/2018]; Патруль на двоих, https:// rg.ru/2017/10/31/kak-rabotaet-edinaia-sistema-pvo-rossii-i-belarusi.html [accessed on 10/03/2018]. ${ }_{25}^{25}$ Алесин А., ЕРС ПВО: старт, растянувшийся на годы. Беларуская прауда, http://belprauda.org/ ers-pvo-start-rastyanuvshijsya-na-gody/ [accessed on 12/03/2018]; Под единым щитом ПВО - Во славу Родины, https://vsr.mil.by/2018/08/16/pod-edinym-shhitom-pvo/ [accessed on 13/03/ 2018]; Гольц А., Союз с оговорками, https://newtimes.ru/articles/detail/116424/ [accessed on 15/03/2018].
} 
Russia is interested in increasing its military influence in Belarus despite of Lukashenko's efforts to develop military cooperation according to his interests with the aim to get specific political, economic and financial benefit and taking into consideration his personal interests. A good example could be the order signed by Lukashenko in 2016 based on which special purposes forces could be used in the territories of the both countries to conduct anti-terrorist operations ${ }^{26}$. This move could be seen as Lukashenko's tool of protection or security in case his regime faces a real threat. On the other hand, this shows that Russia obtains more opportunities to use its armed forces in the territory of Belarus as to date operation of armed forces has been limited to the case of a war or only as a component of joint exercises.

\section{Military-Technical Cooperation: Accomplishments and Challenges of Integration Reality}

As is known, Russia is the main partner and supplier of Belarus in the military and technical area. Due to the signed and newly or previously concluded long-term cooperation agreements in the field of defence, Russia remains the key supplier of raw materials, new and renewed (modernised) weaponry with regard to the Belorussian military industry complex and at the same time - the main purchaser of its products. Sometimes Russia offers Belarus exceptional preferential conditions and grants credits thus subsidising the acquisition of armament. This demonstrates that the level of integration of the both countries' military industry is very high. Can we thus talk about further enhancement of the alliance's endurance?

In accordance with the military-technical cooperation agreement signed between Belarus and Russia at the end of 2013, a few priority strands were defined for the period up to 2020 as follows: first, cooperation of military companies in creating new and modernised weaponry, military machinery, dual or special purpose products; second, integration of the companies of military-industrial complex; third, development of a single policy in the fields of standardisation and filing; fourth, supply/provision of the Belorussian military

\footnotetext{
${ }^{26}$ Заквасин А., Хлусова К., Союзное войско: чего достиг военный блок России и Белоруссии за 20 лет существования, https://russian.rt.com/ussr/article/374321-rossiya-belorussiya-voennoesotrudnichestvo [accessed on 17/03/2018]; Российскому спецназу разрешат спецоперации на территории Беларуси, https://naviny.by/article/20161212/1481558986-rossiyskomu-specnazu-razreshatspecoperacii-na-territorii-belarusi [accessed on 18/03/2018].
} 
purpose products/services to Russia; and fifth, supply/provision of the Russian military purpose products/services to Belarus. Annexes to this document include specific activities which demonstrate that the content of cooperation speaks of traditional areas, hence intensification may be recorded. The plans include the development of joint scientific research so as to create a new and modernised weaponry and military machinery but the extent of such activities is extremely small and is mentioned only in separate and fairly narrow segments, such as, automation of the management of a mechanised riflemen's battalion, creation of new vehicles, creation of photography equipment for spatial/cosmic devices, standardisation and filing of military products. A few more significant activities are provided for in the integration of companies of the military-industrial complex in order to set up a joint company assembling helicopters and repairing as well as refurbishing aircraft IL-76. Greater plans are drawn up for the development of cooperation in the field of military weaponry. In fact, the scope of supply from Belarus to Russia encompasses as little as 10 positions, and the potential majority of supplies include assembled components (for sights, chassis, complex components for radio locators) and services of repair, refurbishment and maintenance of aircraft IL-76 based on orders from foreign countries. In this case, Russia plays the role of a subcontractor.

The estimated scope of Russia's military products intended for the partner is much greater - it occupies as many as 33 positions. These are not only repair and maintenance of military weaponry and machinery, supply of ammunition, assembled components, staff training but also modernisation of new military armament, such as of helicopters Mi-8, aircraft Jak-130, fighter aircraft Su-30, unmanned intelligence devices, zenith-rocket complex TorM2E, also tank T-72 $2^{27}$. Thus a few evident things can be seen: a big disproportion between the potential military-industrial complexes, dependence of military industry of Belarus on Russia and its specialisation exclusively in manufacturing of assembled components.

It must be noted that projects on the development of infrastructure intended for the united regional armed forces are given increasingly more attention. There is a new programme which focuses on the development of common infrastructure necessary for this structure: repair of an airfield in Russia, two

\footnotetext{
${ }^{27}$ Соглашение между Правительством Республики Беларусь и Правительством Российской Федерации о реализации Программы военно-технического сотрудничества между Республикой Беларусь и Российской Федерацией до 2020 года, http://naviny.org/2013/12/25/by4527.html [accessed on 19/03/2018]; Поротников А., Получит ли Беларусь „свой“ танк?, https://www.sn-plus.com/ru/page/ politics/9176/ [accessed on 20/03/2018]; idem, Беларусь и Россия: призрачное единение, http://www. sn-plus.com/ru/page/politics/8458/ [accessed on 20/03/2018].
} 
airfields and radiolocation centre in Belarus as well as major repairs of other objects of old infrastructure (warehouses of weapons and ammunition, other buildings of military purpose) - again, mostly in Belarus (44) and some in Russia (16). Funds are allocated from the budget of the unified state. Renewal of railway infrastructure is also linked to joint armed forces as more finances have been granted compared to the previous programme. Most often, Russia's financial contribution is considerably greater than that of Belarus ${ }^{28}$.

In addition to these projects, the expansion of the logistical system takes place. In 2017, agreement signed by the countries in 2005 on the provision of supplies to regional forces was renewed. The agreement names specific actions of both countries aimed at supplies in case of a crisis or war. Article 7 of the agreement should be given some special consideration as it stipulates that supplies and reserves of ammunition, weaponry, combat machinery and other material valuables "in the period of a growing military threat" and collected and stored in the warehouses of Russia's army in peacetime may be moved to Belarus. The agreement states that in case of war, the Belorussian material technical base and collected reserves shall be used jointly. It should be noted that this supplement with a fairly freely interpreted definition of the "in the period of a growing military threat" (formerly, "in the period of aggression") allows Russia to have in its disposition considerably greater additional combat resources in the event of redeployment of Russia's armed forces to the territory of Belarus ${ }^{29}$. The said new programmes demonstrate strenuous efforts of the both countries, especially Russia's, to activate military integration. Following the examination of the content of the prospective plans, it is reasonable to move to the discussion of their practical implementation.

The fulfilment of military-technical cooperation plans and absence of any great problems is stated on the top governmental level, however, Belorussian and Russian military experts speak of the existing disagreements arising

\footnotetext{
${ }^{28}$ Belarus allocated RUB 420,000,0, meanwhile, Russia granted RUB 779,991,2. Программа „Совершенствование объектов военной инфраструктуры, планируемых к совместному использованию в интересах обеспечения региональной группировки войск (сил) Республики Беларусь и Российской Федерации“ на 2018-2021 гг. Belarus allocated RUB 594,623, 5, meanwhile, Russia - RUB 1104 234, 9. Программа „Развитие и совершенствование единой системы технического прикрытия железных дорог региона“ на 2016-2020 гг., https://www.postkomsg.com/programs/ [accessed on 22/03/2018].

${ }^{29}$ Соглашение между Правительством Российской Федерации и Правительством Республики Беларусь о совместном техническом обеспечении региональной группировки войск (сил) Российской Федерациии Республики Беларусь, http://www.mid.ru/foreign_policy/international_contracts/2_contract/-/storage-viewer/bilateral/page-23/51724 [accessed on 22/03/2018].
} 
out of different political and economic motives ${ }^{30}$. Russia puts every effort to avail of relatively small potentials of the Belorussian military-industrial complex. The best way to do that is to purchase the main companies, such as Integral, the heavyweight tow-vehicle factory in Minsk, MAZ vehicle plant, Peleng and other. The President of the Republic of Belarus Alexander Lukashenko seeks to preserve profit-making companies which are an important source of income for the state budget and wants to reserve the opportunity to have better bargaining position in negotiations with Russia. The said integration plan on military-industrial complex does not provide for the privatisation until the year 2020 and speaks of establishment of joint companies; however, the list does not contain the main military companies of Belarus. Thus cooperation of the both partners occurs in the context of controversial interests with public demonstration of permanent disagreements. Russia periodically shows its tactical aim to take a stronger stance in the military industry of Belarus. Belorussian companies are prevented from free competition in the Russian market with regard to profitable orders and the attempts to find a replacement for the Belorussian military products is demonstrated occasionally, for instance, in 2016, the alleged transfer of vehicle chassis of the most important heavyweight truck factory in Minsk to the Russian vehicle factory Kamaz was put at the forefront. Lukashenko publicly demanded to sell a petroleum extraction company as a compensation in such a case. In its turn, Belarus would like to obtain the most advanced weapons, for instance, rocket complex S-400, under preferential conditions from Russia ${ }^{31}$.

Independent actions of Belarus in looking for new markets for military products in the third countries (China, Thailand, Egypt) are not desired from the point of view of Russia. In 2015, Belarus sold 294 MAZ vehicles of military purpose to Ukraine ${ }^{32}$. On the other hand, the Belorussian military company

\footnotetext{
${ }^{30}$ В приоритете „Паритет“; https://vpk.name/news/250166_v_prioritete_paritet.html [accessed on 23/03/2018].

${ }^{31}$ Belarmy news. Россия готова скупить белорусскую оборонку, http://belarmy.by/novosti/rossiyagotova-skupit-belorusskuyu-oboronku) [accessed 201804 05]; Данейко Е., Сотрудничество Беларуси и России в сфере ВПК: партнеры или конкуренты?“", http://p.dw.com/p/2YXhE/ [accessed on 05/04/ 2018]; Поротников А., О военной организации «союзного государства», http://www.sn-plus.com/ru/ page/politics/9139/ [accessed on 05/04/2018]; Зверев Ю., Военно-техническое сотрудничество России и Беларуси: перспективы и риски, https://eurasia.expert/voenno-tekhnicheskoe-sotrudnichestvo-rossiii-belarusi-perspektivy-i-riski [accessed 201804 05]

${ }^{32}$ Bohdan S., Belarusian arms industry struggles to survive under Kremlin pressure, https://belarusdigest.com/story/belarusian-arms-industry-struggles-to-survive-under-kremlin-pressure/ [accessed on 06/04/2018]; Golts A., Belarus and Russia: Military Cooperation but with Different Goals, Belarusian Foreign Policy:360 . p. 93; Заяц А., Не процветаем, но и не дохнем "Интеграл“"интегрируют в Российскую электронику, Новости ВПК, https://vpk.name/news/86499_ne_procvetaem_no_i_ne_ dohnem_integral_integriruyut_v_rossiiskuyu_elektroniku.html [accessed on 05/04/2018].
} 
has started demonstrating the first results of military manufacturing: first, in terms of armed vehicles - serial production line of Kaiman has been launched for military purposes; rocket system Polonez has also reached the stage of production ${ }^{33}$. In the general context of technological dependence of Belarus on Russia, these are only small exceptions and the prospect of independent development is weak due to the obvious lack of financial and human resources. However, recently the Belorussian military industry has attempted to find and make use of the niche which emerged after Russia started disposing of the old weaponry. Belarus is successful in modernising and maintaining the old Russian weaponry owned by the third countries since the Russian companies and corporations no longer provide such services. This is one more segment of the military industry that brings money to the budget of Belarus.

\section{Conclusions}

The discussed situation may be firmly assessed as a new stage of strengthening of the military cooperation between Russia and Belarus with Russia being the initiator in the context of the ongoing conflict with the West. Thus Russia aims at enhancing its military power availing of and controlling the military potential of Belarus. For the last five years, the endurance of the alliance was strengthened by the activation of cooperation: the aims of military integration can be recorded in the new documents of strategic level - military doctrines, old projects have been finalised (air space defence system) and new initiatives have been put into action, more specifically, all effort is put in trying to implement what was declared a few decades ago in the strategic documents of the both countries. The level of interoperability of armed forces has significantly increased due to a rapid growth of joint strategic exercises; for this reason, their capability to carry out joint combat tasks expediently has dramatically strengthened. Processes of intensification of military and technical cooperation are not so much pronounced, but evident shifts have taken place while developing a common military infrastructure. This helps ensure the opportunities of use and growth of the combat potential of the unified regional armed forces. The important thing is that in the stage of development of a military alliance, Russia has considerably expanded the opportunity to use its

\footnotetext{
${ }_{33}^{3 в е р е в ~ Ю ., ~ « П о л о н е з ы », ~ б е с п и л о т н и к и ~ и ~ р о б о т ы: ~ с е к р е т ~ у с п е х а ~ б е л о р у с с к о г о ~ В П К . ~ Е в р а з и я ~}$ Эксперт, http://eurasia.expert/polonezy-bespilotniki-i-roboty-sekret-uspekha-belorusskogo-vpk/ [accessed on 05/04/2018]; Bogdan S., Minsk silently builds a new army. Belarus Digest, https://belarusdigest. com/story/minsk-silently-builds-a-new-army/ [accessed on 05/04/2018].
} 
armed forces gaining the support of the Belorussian armed forces and making use of the territory of Belarus for its potential military actions.

Nevertheless, regardless the stage of intensified cooperation, the main factor which slows down the pace of integration has remained unchanged. In other words, Belarus is still willing to preserve a certain status quo, despite the active pressure from Russia. On the one hand, in the period of growing economic and political dependence on Russia, it is vitally important for the president Lukashenko to reserve, have in his disposition and demonstrate both to the domestic and international audience the signs of a policy which represents own interests. On the other hand, Belarus is interested in the prospect of strategic military partnership merely for the fact that by making use of the mechanisms of military cooperation it can strengthen and modernise the Belorussian armed forces at the expense of Russia. Given the scope of the present military expenses, this would be very difficult for Belarus, especially having in mind the fact that the country has no potential alternatives. Therefore, in the short term, under the conditions of consolidated personal political regimes, military cooperation will most probably not face any new challenges and will be developed at a slow pace.

May 2019 